\title{
Influence of extreme hydrological events in the quality of water reservoirs in the semi-arid tropical region
}

\section{Influência de eventos hidrológicos extremos na qualidade da água de reservatórios na região tropical semiárida}

\author{
Aline do Vale Figueiredo ${ }^{1}$ and Vanessa Becker ${ }^{2}$ \\ ${ }^{1}$ Universidade Federal do Maranhão, São Luís, MA, Brasil \\ ${ }^{2}$ Universidade Federal do Rio Grande do Norte, Natal, RN, Brasil \\ E-mails: alinefigueiredo_@hotmail.com (AVF), becker.vs@gmail.com (VB)
}

Received: May 31, 2018 - Revised: August 08, 2018 - Accept: October 03, 2018

\begin{abstract}
Inland water environments, such as natural and artificial lakes, are increasingly vulnerable to extreme events (heavy rains, severe drought). This study aims to evaluate if this events affect the water quality of tropical semi-arid springs. The results showed that the reservoirs presented significant changes in the limnological variables between the rainy season and severe drought periods. However, different behaviors were observed among reservoirs in the period of severe drought, which indicate that the responses of these environments to extreme events should take into account other factors such as the climate of the region, the size and depth of the reservoir.
\end{abstract}

Keywords: Severe drought; Limnological variables; Hydrological regime; Drylands.

\section{RESUMO}

Ambientes de águas interiores como lagos naturais e artificiais estão cada vez mais vulneráveis as ações dos eventos extremos (chuvas intensas, seca severa). O estudo tem como objetivo avaliar se esses eventos afetam a qualidade da água de mananciais do semiárido tropical. Os resultados do estudo mostraram que os reservatórios apresentaram mudanças significativas nas variáveis limnológicas entre os períodos de chuva e de seca severa. Entretanto, constataram-se comportamentos distintos entre os reservatórios no período de seca severa indicando que as respostas destes ambientes na problemática dos eventos extremos devem levar em consideração outros fatores como o clima da região, tamanho e profundidade do reservatório.

Palavras-chave: Seca severa; Variáveis limnológicas; Regime hidrológico; Regiões secas.

\section{INTRODUCTION}

The climatic and hydrological factors play important roles in the input, output, water level and water residence time of the reservoirs, directly affecting the limnological patterns (NASELLI-FLORES; BARONE, 2005; SOARES et al., 2012). Seasonal fluctuations in reservoir water levels are associated with changes in the physical, chemical and biological characteristics of these systems and may result in a decrease in water quality in aquatic ecosystems during periods characterized by low rainfall and reduced water volumes (ARFI, 2003; NASELLI-FLORES; BARONE, 2003; ROCHA JÚNIOR et al., 2018). In addition, global or local climatic changes, when affect the hydrological regime, may compromise the water quality of the water sources, especially as regards the eutrophication process (BRAGA; BECKER; MATTOS, 2015).

Intensive rains of short duration lead to greater soil erosion and nutrient distribution, and therefore, an increase in phosphorus intake in lakes via tributaries is expected, especially in cases of drainage basins with agricultural use and history of fertilizers (MOOIJ; 
DE SENERPONT DOMIS; JANSE, 2009; MOSS et al., 2011). On the other hand, prolonged drought events cause water levels to fall, concentrating nutrients there, a favorable condition for the excessive growth of cyanobacteria (MOSS et al., 2011).

In recent years, extreme events (floods, prolonged droughts) have been experienced with greater severity and the period between them seems to have become shorter in certain regions (MISHRA; SINGH, 2010). In addition, global climate change models are predicting their higher frequency, which will create hydrological stresses in water bodies (IPCC, 2014). In the northeastern semi-arid we can already see the occurrence of these events, the drought of the years 2012, 2013 and 2014 was the worst drought of the last 60 years, according to the National Water Agency (ANA).

The semi-arid regions are characterized by annual precipitation between 400 and 800 millimeters with a rainy season that normally occurs between January and July, but presenting spatial and temporal amplitude variation (BARBOSA et al., 2012). The long dry annual period, characterized by absence and scarcity as well as by the high spatial and temporal variability of rains, raises the local temperature, characterizing seasonal aridity (VIEIRA, 2002). Even for this region, high temperatures and low precipitation can result in an increase in eutrophication and salinization of surface waters and, as a consequence, an increase in the occurrence of cyanobacteria blooms, which is already usually reported (HUSZAR et al., 2000; MEDEIROS et al, 2015; COSTA;
ATTAYDE; BECKER, 2016). These regions, with such peculiar characteristics, need to demand for the management of their water resources, as they can be affected by hydrological events can be carried out by socioeconomic problems due to insufficient water available are unfit for any uses in the hydrographic basin (BRAGA; BECKER; MAT'TOS, 2015).

Therefore, the present study aims to evaluate if extreme hydrological events (intense rainfall and prolonged drought) affect the water quality of tropical semi-arid springs.

\section{MATERIALS AND METHODS}

\section{Study area}

The objects of this study are the reservoirs Gargalheiras (06 $\left.25^{\circ} 30^{\prime \prime S} / 36^{\circ} 36^{\prime} 09^{\prime \prime} \mathrm{W}\right)$ and Cruzeta (06 24'42 “S/36 47'23”W), both part of the river basin Piranhas-Açu and are located in the northeastern semi-arid region of Brazil (Figure 1). Its waters are used for human supply, irrigation, animal watering and recreation, and riparian zones for agriculture and domestic activities.

Gargalheiras was built in 1959, through the Acauã river bus, has an area of 805.67 ha, maximum accumulation capacity of 44.4 million $\mathrm{m}^{3}$ and maximum depth of 26.5 meters. Cruzeta is a smaller system and was built in 1929 through the São José
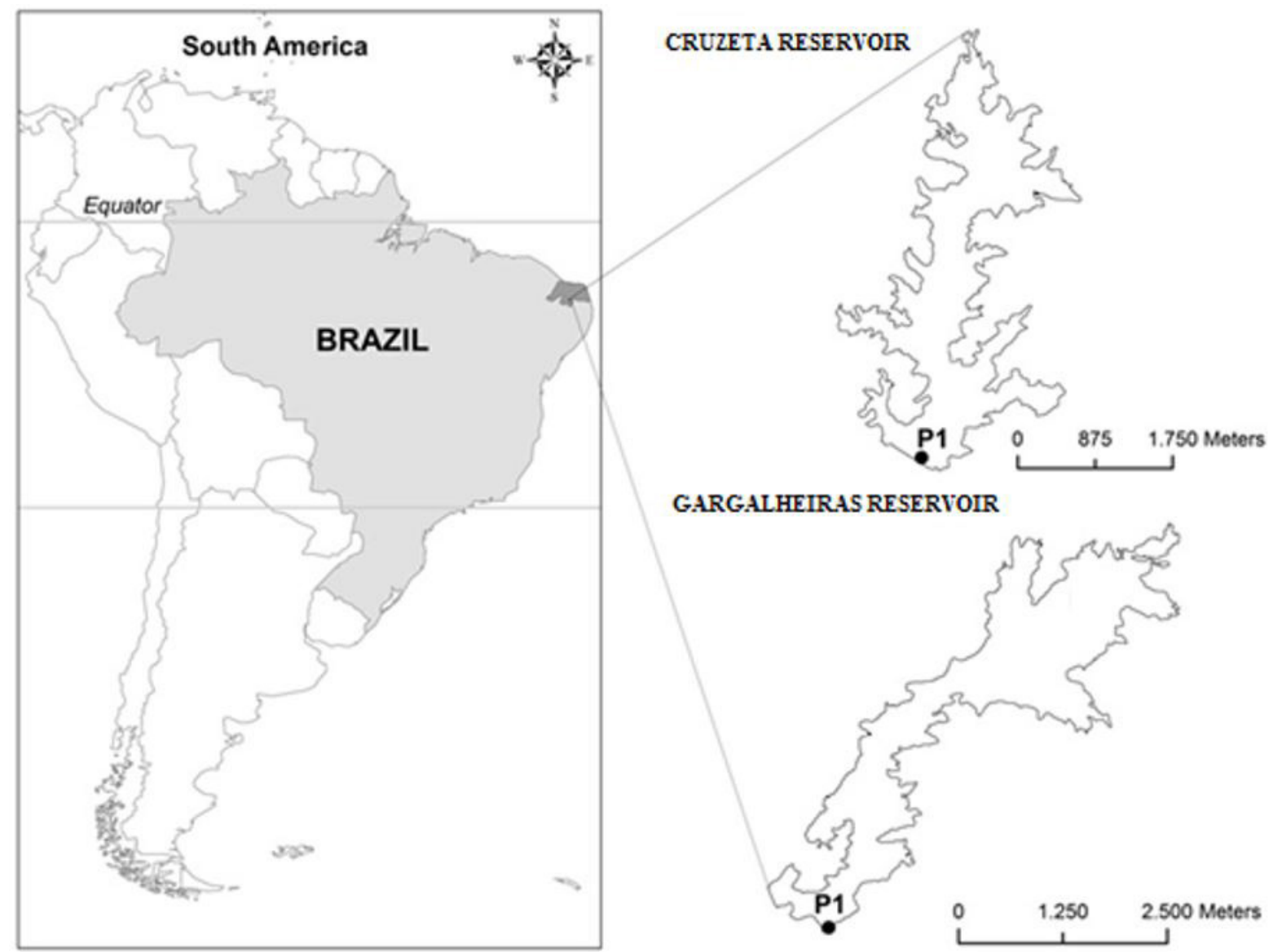

GARGALHEIRAS RESERVOIR

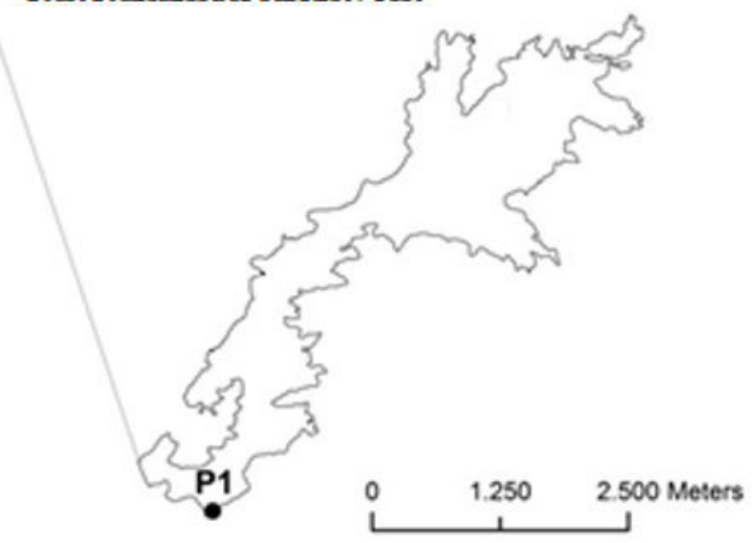

Figure 1. Geographical location of Cruzeta reservoir and Gargalheiras reservoir, showing the sample station (P1). 
stream. It has an area of 616,11ha, a maximum accumulation capacity of 23,5 million $\mathrm{m}^{3}$ and a maximum depth of 15 meters.

\section{Sampling}

Samples were collected monthly in the Gargalheiras and Cruzeta reservoirs from July 2010 to May 2014. The samples were always collected at the sampling point near to the dam, the deepest point of the reservoir and where water is collected for water supply.

The vertical profiles of temperature and dissolved oxygen were measured through the HIDROLAB DS5 multi-probe at 1-meter intervals from the surface to the bottom of the reservoir. The transparency of the water was measured with the help of the Secchi disk.

Integrated samples of the epilimnium were also collected with Van Dorn bottle, according to the oxygen profile, provided by the multiparametric probe. The subsamples were conditioned in polyethylene bottles, previously washed with 10\% HCL and deionized water, and packed in iceboxes during transport to the laboratory.

\section{Sample analysis}

Electric conductivity were measured by specific portable equipment (AP2000). Total and inorganic suspended solids (ISS) were determined by gravimetry after drying the filters overnight at $100{ }^{\circ} \mathrm{C}$ and the ignition of filters at $500{ }^{\circ} \mathrm{C}$ for $3 \mathrm{~h}$ (APHA, 2012). The organic suspended solids (OSS) were measured by the difference between total suspended solids and inorganic suspended solids (APHA, 2012).

Soluble reactive phosphorus (SRP) and nitrate (NO3-) was measured spectrophotometrically on water filtered on $0.45-\mu \mathrm{m}$ glass-fiber filters (MURPHY; RILEY, 1962). Total phosphorus (TP) was analyzed by the ascorbic acid method after oxidation with potassium persulfate (VALDERRAMA, 1981). Chlorophyll-a was extracted with ethanol $95 \%$ and measured by spectrophotometry (JESPERSEN; CHRISTOFFERSEN, 1987).

\section{Data analysis}

The data on the monthly rainfall and the time series of the region were provided by the Agricultural Research Company of the state of Rio Grande do Norte (EMPARN). Based on this information and the Standardized Precipitation Index (SPI) (MCKEE; DOESKEN; KLEIST, 1993), provided by the National Institute of Meteorology (INMET), the months were divided into two periods: period I as being of heavy rainfall and period II as being of severe drought. This index is based on the probability of precipitation for different time scales and evaluates the severity of the drought.

The volumes stored and their variations in the reservoirs throughout the study period were provided by the State Secretariat for the Environment and Water Resources of Rio Grande do Norte (SEMARH).
Statistical statistical analyzes and linear regression were performed with the aid of the Statistica program a to assess which limnological variables varied significantly with volume. The principal component analysis (PCA) was performed for each reservoir, with data on volume, water transparency, electrical conductivity, organic and inorganic solids, reactive soluble phosphorus, nitrate, total phosphorus and chlorophyll a using PC program -ORD ${ }^{\circledR}$ v.6 (MCCUNE; MEFFORD, 2011) in order to verify the temporal gradients of limnological variables during the periods studied.

\section{RESULTS}

\section{Meteorological and hydrological scenario}

The study period was subdivided according to SPI12 by INMET, where the months were classified as: extremely humid, severely humid, moderately humid, normal, moderately dry, severely dry and extremely dry. According to this index two periods were identified: (I) rainy season - months classified as moderately humid and normal - characterized by rains above average in the rainy months and normal dry months, but under the influence of high precipitations of the previous rainy months; (II) period of severe drought - months classified as moderately dry, severely dry, extremely dry and normal - with rains well below the historical average in the rainy months and normal dry months (Figure 2).

The volumes stored in the Gargalheiras and Cruzeta reservoirs varied during the analyzed period, with volumes around $60 \%$ of their accumulation capacity at the beginning of the study. With rains above the historical average in the first months of 2011 the springs reached $100 \%$ of capacity and overflowed. From this period, with prolonged drought, there was a progressive decrease in storage (Figure 3).

\section{Limnological scenario}

The temperature and dissolved oxygen profiles of the reservoirs showed a tendency to mix in the rainy period and the thermal and chemical stratification in the period of severe drought, highlighting anoxic hypolimnium in this period for Gargalheiras. In this reservoir, the variables maximum depth and water transparency obtained higher average values in the rainy season, while the variables electrical conductivity, $\mathrm{pH}$, inorganic solids, organic solids, total phosphorus, nitrate, reactive soluble phosphorus and chlorophyll had higher mean values in the period of severe drought. The Cruzeta reservoir presented a distinct behavior, since in addition to the maximum depth and the transparency of the water, the organic and chlorophyll a variables also presented higher average values during the rainy season. In the period of severe drought, the variables electrical conductivity, $\mathrm{pH}$, inorganic solids, total phosphorus, nitrate and reactive soluble phosphorus had their relative mean values (Table 1 ).

The results of the linear regression analysis for the Gargalheiras reservoir showed that there was a negative relation of volume with TP $(\mathrm{P}<0.001)$, Chla $(\mathrm{P}<0.001)$ and C $(\mathrm{P}<0.001)$ and positive with water transparency $=0.001)$. The volume 
A

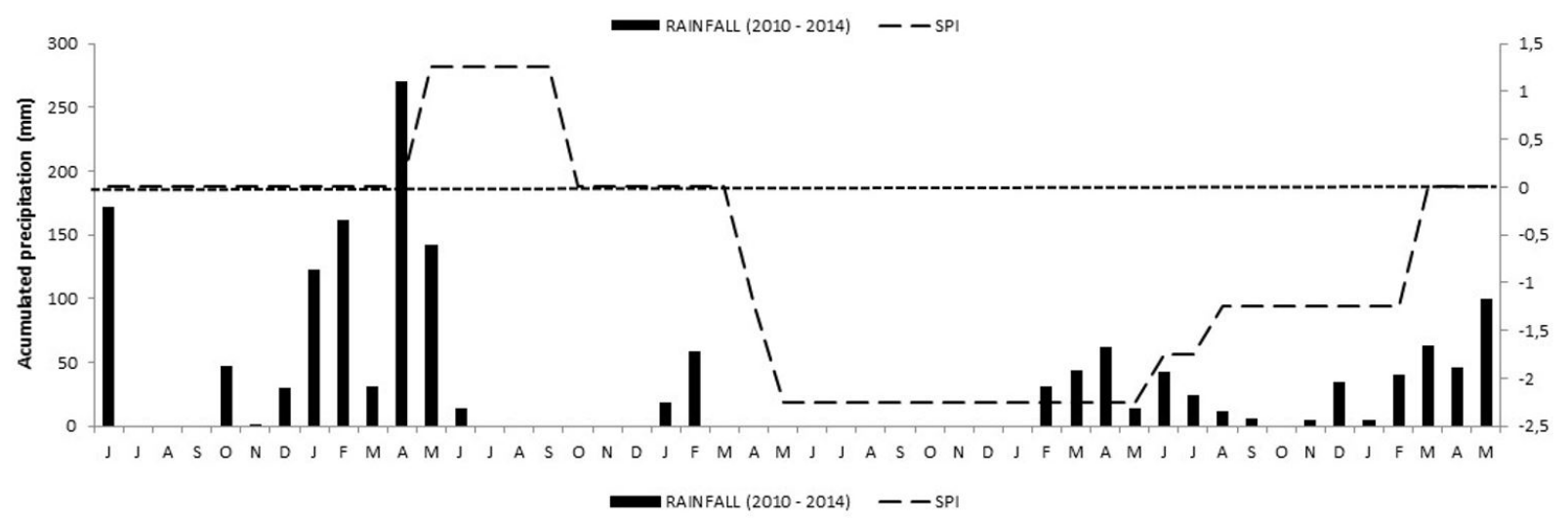

B

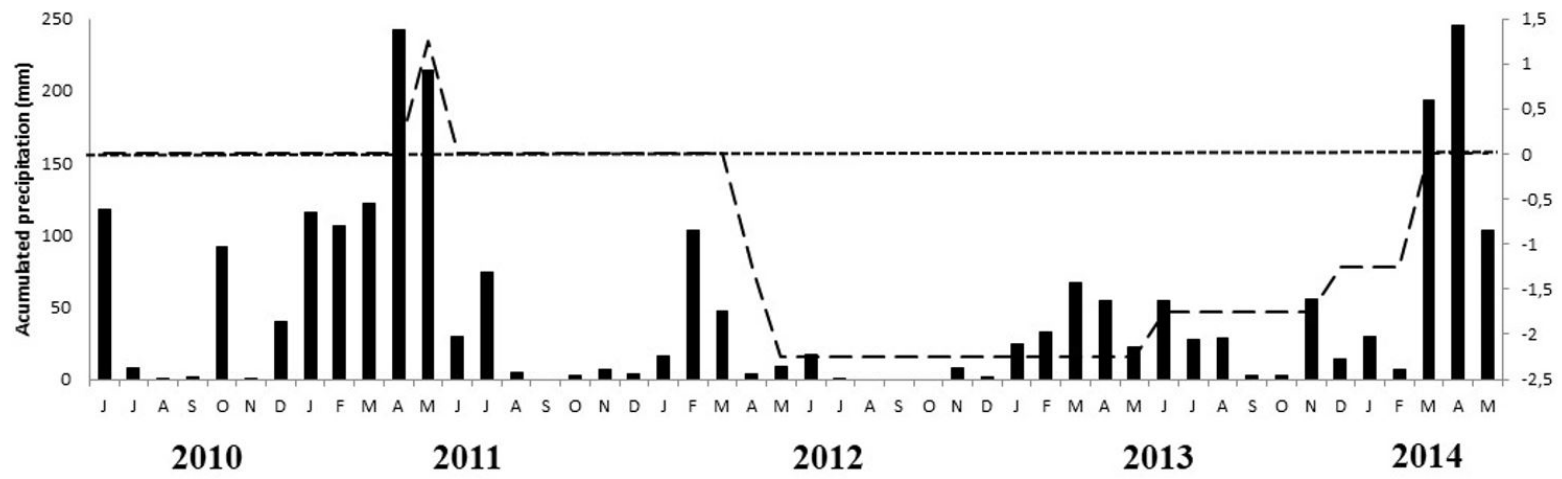

Figure 2. Monthly rainfall accumulated between June 2010 and May 2014, and the rainfall historical average for the period between 1963 and 2013 for the region (Source: EMPARN, 2014). SPI12: months extremely humid, severely humid, moderately humid, normal, moderately dry, severely dry and extremely dry (Source: INMET, 2014). (A) Gargalheiras; (B) Cruzeta.

A

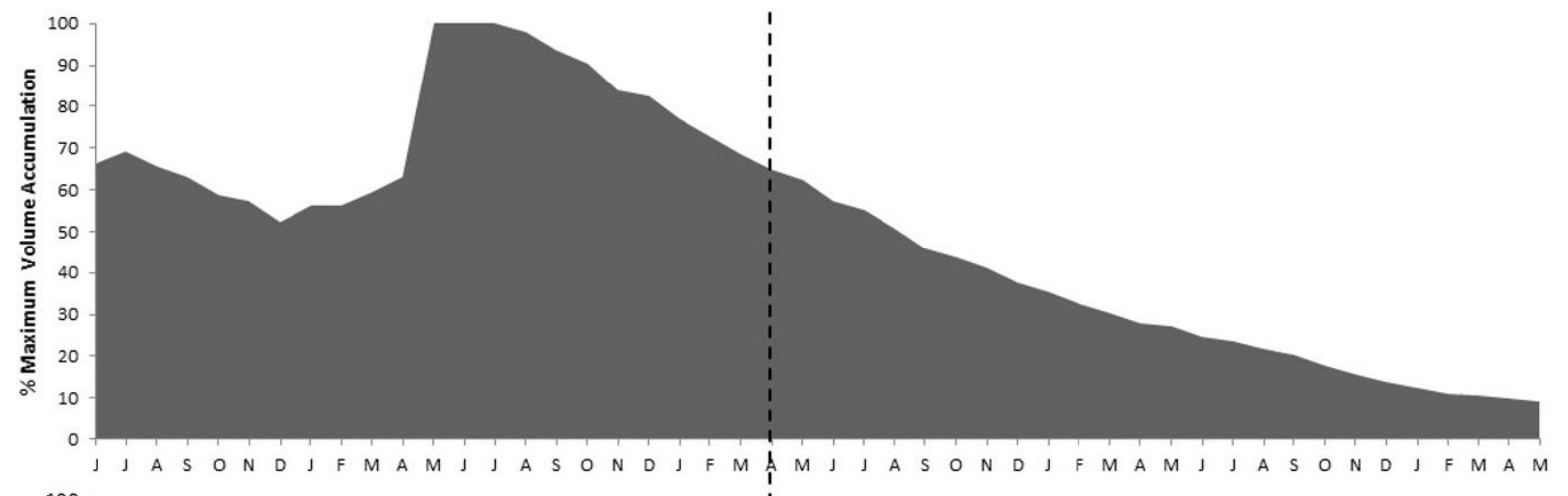

B

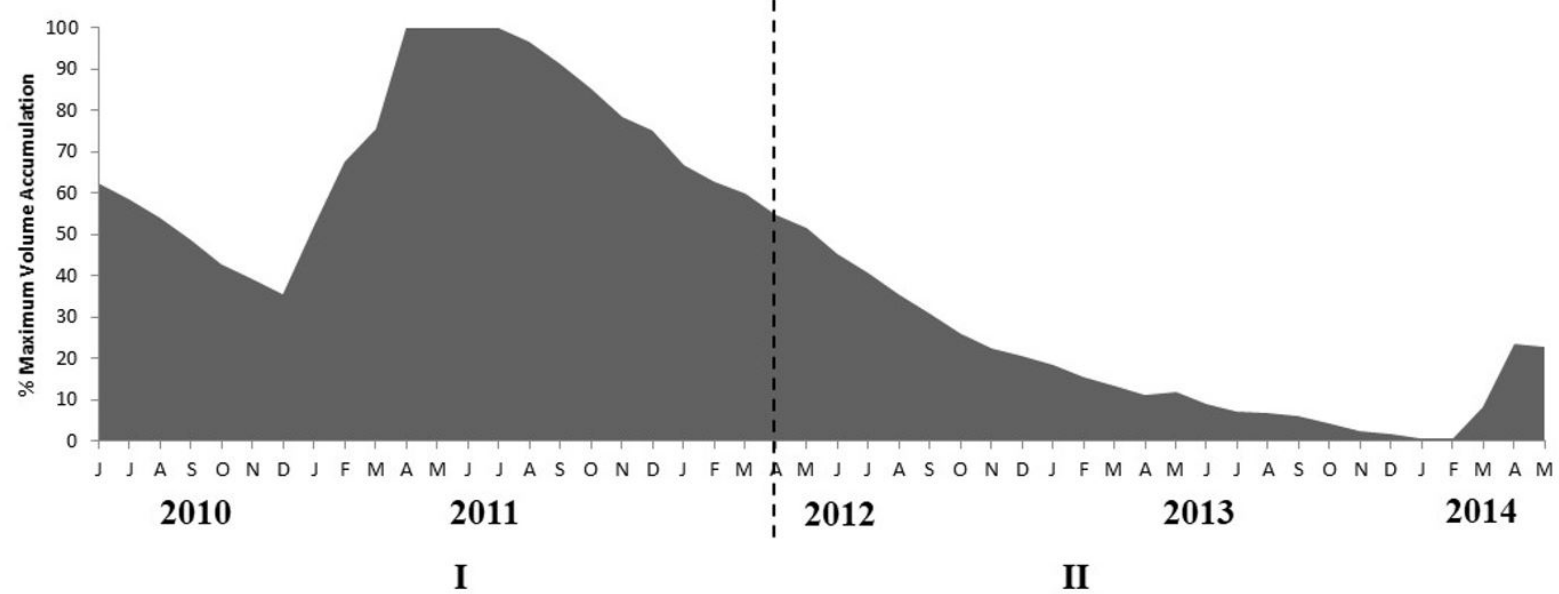

Figure 3. Variation of the volume stored (\%) of the Gargalheiras reservoir and Cruzeta reservoir during the period June 2010 and May 2014. (Source: SEMARH, 2014). (A) Gargalheiras; (B) Cruzeta. 
Figueiredo and Becker

Table 1. Descriptive statistics (minimum, maximum, average and standard deviation) of the limnological variables studied at the Gargalheiras reservoir and Cruzeta reservoir sample station (P1) during periods identified by rainy season and dry season (periods I and II).

\begin{tabular}{|c|c|c|c|c|}
\hline \multirow{2}{*}{ Variables } & \multicolumn{2}{|c|}{ GARGALHEIRAS } & \multicolumn{2}{|c|}{ CRUZETA } \\
\hline & Period I & Period II & Period I & Period II \\
\hline $\mathrm{Zmax}(\mathrm{m})$ & $\begin{array}{c}14.3-20.2 \\
(17.9 \pm 1.9)\end{array}$ & $\begin{array}{c}7.0-19.5 \\
(14.0 \pm 3.0)\end{array}$ & $\begin{array}{c}4.5-8.7 \\
(6.7 \pm 1.2)\end{array}$ & $\begin{array}{c}0.3-5.7 \\
(3.4 \pm 1.4)\end{array}$ \\
\hline Secchi (m) & $\begin{array}{c}0.35-2.10 \\
(0.76 \pm 0.41)\end{array}$ & $\begin{array}{c}0.15-0.50 \\
(0.28 \pm 0.09)\end{array}$ & $\begin{array}{c}0.20-1.00 \\
(0.62 \pm 0.21)\end{array}$ & $\begin{array}{c}0.05-0.80 \\
(0.47 \pm 0.18)\end{array}$ \\
\hline $\mathrm{T}\left({ }^{\circ} \mathrm{C}\right)$ & $\begin{array}{c}23.8-31.0 \\
(27.4 \pm 1.9)\end{array}$ & $\begin{array}{c}24.6-33.7 \\
(28.6 \pm 2.3)\end{array}$ & $\begin{array}{c}24.5-33.9 \\
(28.1 \pm 2.5)\end{array}$ & $\begin{array}{c}24.9-33.4 \\
(29.0 \pm 2.4)\end{array}$ \\
\hline $\mathrm{OD}\left(\mathrm{mg} \mathrm{L}^{-1}\right)$ & $\begin{array}{c}6.79-16.87 \\
(10.87 \pm 2.97)\end{array}$ & $\begin{array}{c}4.10-21.65 \\
(11.17 \pm 4.05)\end{array}$ & $\begin{array}{c}4.17-17.52 \\
(10.16 \pm 3.64)\end{array}$ & $\begin{array}{c}1.40-14.92 \\
(7.33 \pm 2.68)\end{array}$ \\
\hline$C\left(\mu \mathrm{cm}^{-1}\right)$ & $\begin{array}{c}340.0-927.0 \\
(697.7 \pm 150.4)\end{array}$ & $\begin{array}{c}\text { 867.0-2070.0 } \\
(1190.0 \pm 301.2)\end{array}$ & $\begin{array}{c}289.0-1225.0 \\
(683.5 \pm 280.9)\end{array}$ & $\begin{array}{c}210.0-1713.0 \\
(966.1 \pm 429.5)\end{array}$ \\
\hline $\mathrm{pH}$ & $\begin{array}{c}7.7-10.6 \\
(8.8 \pm 0.6)\end{array}$ & $\begin{array}{c}6.7-10.3 \\
(9.2 \pm 0.7)\end{array}$ & $\begin{array}{c}6.7-10.0 \\
(8.3 \pm 0.8)\end{array}$ & $\begin{array}{c}7.7-10.3 \\
(8.4 \pm 0.6)\end{array}$ \\
\hline ISS $\left(\mathrm{mg} \mathrm{L}^{-1}\right)$ & $\begin{array}{c}0.0-18.8 \\
(3.2 \pm 3.9)\end{array}$ & $\begin{array}{c}0.0-13.5 \\
(4.9 \pm 4.0)\end{array}$ & $\begin{array}{c}0.0-11.7 \\
(4.6 \pm 3.6)\end{array}$ & $\begin{array}{c}0.4-29.5 \\
(11.1 \pm 8.1)\end{array}$ \\
\hline OSS $\left(\mathrm{mg} \mathrm{L}^{-1}\right)$ & $\begin{array}{c}0.9-36.5 \\
(11.9 \pm 9.6)\end{array}$ & $\begin{array}{c}6.0-43.6 \\
(24.0 \pm 9.6)\end{array}$ & $\begin{array}{c}4.4-37.4 \\
(12.9 \pm 9.8)\end{array}$ & $\begin{array}{c}0.9-14.0 \\
(6.9 \pm 3.8)\end{array}$ \\
\hline $\mathrm{TP}\left(\mu \mathrm{g} \mathrm{L^{-1 }}\right)$ & $\begin{array}{c}21.67-147.83 \\
(99.42 \pm 30.16)\end{array}$ & $\begin{array}{c}55.20-342.00 \\
(212.17 \pm 91.00)\end{array}$ & $\begin{array}{c}37.23-194.15 \\
(88.80 \pm 52.29)\end{array}$ & $\begin{array}{c}21.20-517.00 \\
(160.14 \pm 133.02)\end{array}$ \\
\hline $\mathrm{NO}_{3}^{-}\left(\mu \mathrm{g} \mathrm{L}^{-1}\right)$ & $\begin{array}{c}42.00-104.46 \\
(78.12 \pm 17.73)\end{array}$ & $\begin{array}{c}46.50-309.50 \\
(133.42 \pm 58.37)\end{array}$ & $\begin{array}{c}24.50-132.59 \\
(87.31 \pm 29.98)\end{array}$ & $\begin{array}{c}42.50-287.50 \\
(136.59 \pm 62.38)\end{array}$ \\
\hline $\operatorname{SRP}\left(\mu g \mathrm{~L}^{-1}\right)$ & $\begin{array}{c}0.00-104.33 \\
(23.45 \pm 28.40)\end{array}$ & $\begin{array}{c}2.57-138.83 \\
(27.63 \pm 39.63)\end{array}$ & $\begin{array}{c}0.00-67.42 \\
(14.48 \pm 17.49)\end{array}$ & $\begin{array}{c}4.50-269.50 \\
(94.28 \pm 69.84)\end{array}$ \\
\hline Chla $\left(\mu g \mathrm{~L}^{-1}\right)$ & $\begin{array}{c}5.82-162.11 \\
(72.17 \pm 48.17)\end{array}$ & $\begin{array}{c}41.25-348.68 \\
(186.78 \pm 70.54)\end{array}$ & $\begin{array}{c}5.86-162.73 \\
(49.59 \pm 41.05)\end{array}$ & $\begin{array}{c}2.40-167.87 \\
(24.14 \pm 34.35)\end{array}$ \\
\hline
\end{tabular}

explained $64 \%$ of the TP variation $(\mathrm{R} 2=0.64)$ and $70 \%$ of the $\mathrm{C}$ variation $(\mathrm{R} 2=0.70)$.

For the Cruzeta reservoir, the linear regression analyzes showed a negative relation with TP $(\mathrm{P}<0.001)$, SRP $(\mathrm{P}<0.001)$, $\mathrm{C}(\mathrm{P}<0.001)$ and NO3- $(\mathrm{P}<0.001)$. The fact that the volume explains $41 \%$ of the variation of the SRP in the reservoir stands out.

Principal component analysis (PCA) also showed distinct behaviors, with sample units segregated between rainy and severe dry periods (Figures 4 and 5).

The PCA of Gargalheiras, with eight limnological variables and water volume, explained $73.9 \%$ of the data (axis 1: $38.9 \%$, axis 2: $35.0 \%$ ). In relation to axis 1 only the reactive soluble phosphorus was correlated (0.99). The most important variables were: volume (-0.79), Secchi (-0.87), electrical conductivity (0.82), organic suspended solids (0.87), total phosphorus $(0.73)$, nitrate (0.47) and chlorophyll a (0.86). Axis $2(\mathrm{P}=0.001)$ presented a temporal trend according to the extreme hydrological events, where on the positive side of the axis were the sample units of the severe drought period and on the negative side of the axis the sample units of the rainy season.

In Cruzeta, the principal component analysis (PCA) using eight limnological variables and water volume explained $73.5 \%$ of the data (axis 1: $54.5 \%$, axis $2: 19.0 \%$ ). The most important variables in the ordering of axis 1 were: volume (0.81), inorganic suspended

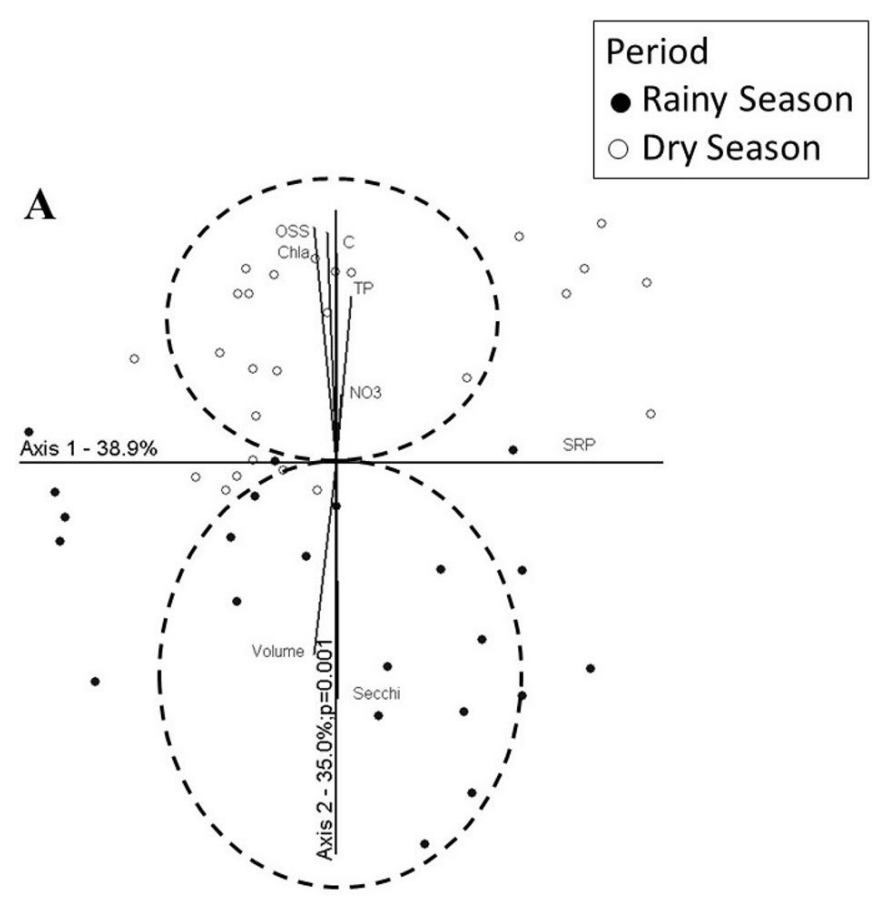

Figure 4. Principal component analysis (PCA) of the Gargalheiras reservoir during the period June 2010 and May 2014, including the limnological variables. 


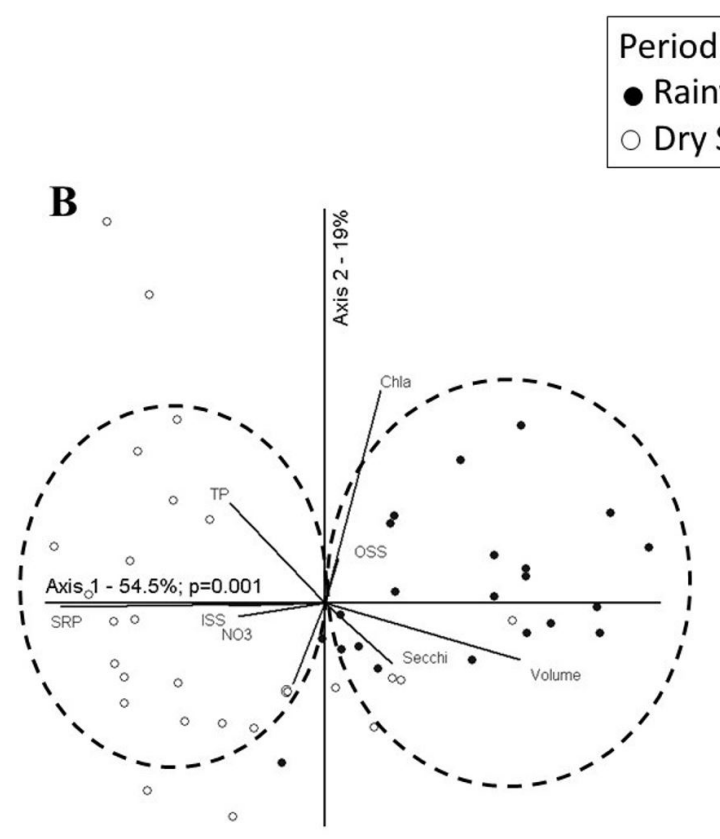

Figure 5. Principal component analysis (PCA) of the Cruzeta reservoir during the period June 2010 and May 2014, including the limnological variables.

solids (-0.57), nitrate (-0.54) and reactive soluble phosphorus (-0.94). In relation to axis 2 , the most important variables were: Secchi (0.47), electrical conductivity (-0.52), total phosphorus (0.58) and chlorophyll a (0.85). Axis $1(\mathrm{P}=0.001)$ showed a temporal trend of the sample units according to the hydrological events, where on the positive side of the axis were related sample units of the rainy season, with higher volume and Secchi and on the negative side of the axis were related the sample units of the period of severe drought with greater electrical conductivity and higher concentrations of total phosphorus, nitrate and inorganic solids.

\section{DISCUSSION}

Inland water environments such as natural and artificial lakes are increasingly vulnerable to extreme events (heavy rains, severe drought), as large variations in water levels lead to changes in the physical, chemical and biological characteristics of the systems (JEPPESEN et al., 2015). In addition, studies indicate that these events will occur more frequently and more intensely in semi-arid regions (IPCC, 2014). In general, the supply sources presented better conditions in the water quality in the rainy season, because with rains above the historical average, both reservoirs reached their maximum capacity and they overflowed, which provided a renewal of their waters and improvement in the visual aspect and in most water quality variables (BEZERRA, 2011; FIGUEIREDO; BECKER; MATTOS, 2014). In contrast, the severe drought period due to the absence of rainfall during the rainy season contributed to the decrease of water quality, with higher concentrations of nutrients, electrical conductivity and suspended solids (GOMES et al., 2015; MENDONÇA JÚNIOR et al., 2018).
It is emphasized the difference of behavior between the environments studied with the occurrence of severe drought, while Gargalheiras (larger and deeper reservoir) presented an accelerated process of eutrophication, Cruzeta (smaller and shallower reservoir) evidenced the collapse of the total phytoplankton biomass due to the low light. This distinct behavior of Cruzeta is atypical for most reservoirs in the semi-arid, which, especially in the dry periods, present high concentrations of algal biomass, indicative of accelerated eutrophication with possible cyanobacterial blooms (ESKINAZI-SANT'ANNA et al., 2006). The high concentrations of inorganic solids detected in the reservoir in the drought period caused high turbidity in the water column, caused by the resuspension of the sediment through the action of the winds and the fish, due to the low depth in the period of severe drought, inhibiting the growth of the Phytoplankton and, consequently, chla concentrations, as well as the change in the composition of functional groups (MEDEIROS et al., 2015; COSTA; ATTAYDE; BECKER, 2016; COSTA et al., 2018).

This behavior was also confirmed by the profiles of temperature and dissolved oxygen, where Gargalheiras and Cruzeta presented more homogeneous profiles during the rainy season, with the water column being mixed with heavy rains and thermal and chemical laminations in most months Dry, with anoxic hypolimnium in Gargalheiras, evidencing that during the period of severe drought there were not enough precipitations to move the water column and to renew the water, as already reported in previous studies (BEZERRA, 2011; FIGUEIREDO; BECKER; MATTOS, 2014).

The principal component analysis (PCA) reiterates this distinction in response to severe drought. In Gargalheiras, the sample units of the rainy season were ordered with greater volume and transparency of the water and the sample units of the dry period were ordered with high values of electrical conductivity and high concentrations of organic solids, nitrate, total phosphorus and chlorophyll a, Indicating a progressive process of eutrophication as a consequence of the semi-arid conditions (ESKINAZI-SANT'ANNA et al., 2007).

For Cruzeta, the sample units of the rainy season were ordered with the highest volume and the units of the dry period were segregated with higher values of inorganic solids, reactive soluble phosphorus, total phosphorus and nitrate, not being related to the algal biomass, evidencing the inhibition of phytoplankton growth with decreasing biomass through the presence of inorganic solids in the water column (JEPPESEN et al., 2015) and consequent increase in SRP availability in this period. This period of water scarcity leads to a decrease in the water level, which, associated with high temperatures and high residence time of water, intensifies the accumulation and concentrations of nutrients and increases the values of conductivity and salinity, leading to eutrophication and consequent degradation of quality of the water (BEKLIOGLU et al., 2007; BARBOSA et al., 2012; JEPPESEN et al., 2015). Recent studies confirm that most of the semiarid reservoirs have been showing high concentrations of nutrients, solids and algal biomass in severe drought. (GOMES et al., 2015; MEDEIROS et al., 2015; BRAGA; BECKER; MATTOS, 2015; COSTA; ATTAYDE; BECKER, 2016; ROCHA JÚNIOR et al., 2018). Therefore, factors such as the climate of the region, size, depth, in addition to the 
characteristics of the basins of the reservoir should be taken into consideration in the study of reservoirs during extreme events.

\section{CONCLUSIONS}

Our results indicate that extreme events, such as intense rains and severe drought, directly affect the limnological variables indicative of water quality in semi-arid reservoirs.

Contrary to what was expected for the semi-arid reservoirs, deeper springs tend to present an increasy eutrophication while shallower springs present collapse in the total phytoplankton biomass.

The different behaviors among the studied reservoirs indicate that the responses of these environments to the problematic of extreme events should also take into account factors such as the climate of the region and morphometric variables such as the size and depth of the reservoir.

\section{ACKNOWLEDGEMENTS}

We are thankful to FINEP (Funding of Studies and Projects) process $n^{\circ} 52009$, and CNPq (National Council of Scientific and Technological Development) process number 483950/2011-4, for financial support. We are grateful to Dr. Arthur Mattos (in memoriam) for his dedication and to Anderson Felipe de Medeiros Bezerra, Ângela Freitas Galvão, Herison Alves de Oliveira, José Neuciano Pinheiro de Oliveira, Kátia B. Miranda, Gustavo Girão Braga, Laíssa de Macêdo Torres, Larissa M.C. Cavalcanti, Mariana R.A. da Costa, Jurandir de Mendonça Junior, Maria da Conceição de Souza, Radmila Salviano and Rudah Marques Maniçoba for technical support (at field work and laboratory analyses). We also thanks to Leandro Gomes for creating the localization map.

\section{REFERENCES}

APHA - AMERICAN PUBLIC HEALTH ASSOCIATION. Standard methods for the examination of water and waste-water. 22th ed. Washington: APHA, AWWA, W.E.F. Washington, 2012.

ARFI, R. The effects of climate and hydrology on the trophic status of Sélingué reservoir, Mali, West Africa. Lakes and Reservoirs: Research and Management, v. 8, n. 3, p. 3-4, 2003.

BARBOSA, J. E. L.; MEDEIROS, E. S. F.; BRASIL, J.; CORDEIRO, R. S.; CRISPIM, M. C. B.; SILVA, G. H. G. Aquatic systems in semi-arid Brazil: limnology and management. Acta Limnologica Brasiliensia, v. 24, n. 1, p. 103-118, 2012. http://dx.doi.org/10.1590/ S2179-975X2012005000030.

BEKLIOGLU, M.; ROMO, S.; KAGALOU, I.; QUINTANA, X.; BÉCARES, E. State of the art in the functioning of shallow Mediterranean lakes: workshop conclusions. Hydrobiologia, v. 584, n. 1, p. 317-326, 2007. http://dx.doi.org/10.1007/s10750-007-0577-x.

BEZERRA, A. F. M. Balanço de massa de fósforo e a eutrofização em reservatórios do semiárido do rio grande do norte - Brasil. 2011. $101 \mathrm{f}$.
Dissertação (Mestrado em Engenharia Sanitária) - Universidade Federal do Rio Grande do Norte, Natal, 2011.

BRAGA, G. G.; BECKER, V.; MATTOS, A. Os efeitos da seca prolongada no processo de eutrofização de um manancial da região semiárida. In: SÍMPÓSIO BRASILEIRO DE RECURSOS HÍDRICOS, 21., 2015, Brasília. Anais... Brasília: ABRH, 2015. Available from: <http://www.evolvedoc.com.br/sbrh/detalhes-818_ os-efeitos-da-seca-prolongada-no-processo-de-eutrofizacao-deum-manancial-da-regiao-semiarida>. Access on: 19 Oct. 2018.

COSTA, M. R. A.; ATTAYDE, J. L.; BECKER, V. Effects of water level reduction on the dynamics of phytoplankton functional groups in tropical semi-arid shallow lakes. Hydrobiologia, v. 778, n. 1, p. 75-89, 2016. http://dx.doi.org/10.1007/s10750-015-2593-6.

COSTA, M. R. A.; MENEZES, R. F.; SARMENTO, H.; ATTAYDE, J. L.; STERNBERG, L. S. L.; BECKER, V. Extreme drought favors potential mixotrophic organisms in tropical semi-arid reservoirs. Hydrobiologia, p. 1-12, 2018. https://doi.org/10.1007/ s10750-018-3583-2.

EMPARN - EMPRESA DE PESQUISA AGROPECUÁRIO DO RIO GRANDE DO NORTE. Dados de precipitação. Natal, 2014. Available from: < http//www.emparn.rn.gov.br//>. Access on: 11 Dec. 2014.

ESKINAZI SANT’ANNA, E. M.; PANOSSO, R. F; ATTAYDE, J. L.; COSTA, I. A. S.; SANTOS, C. M.; ARAÚJO, M. F. F.; MELO, J. L. S. Águas potiguares: oásis ameaçados. Ciência Hoje, v. 39, n. 233, p. 68-71, 2006.

ESKINAZI-SANT'ANNA, E. M.; MENEZES, R.; COSTA, I. S.; PANOSSO, R. F.; ARAÚJO, M. F.; ATTAYDE, J. L. Composição da comunidade zooplanctônica em reservatórios eutróficos do semi-árido do Rio Grande do Norte. Oecologia Brasiliensis, v. 11, n. 3, p. 410-421, 2007. http://dx.doi.org/10.4257/oeco.2007.1103.10.

FIGUEIREDO, A. V.; BECKER, V.; MATTOS, A. O efeito da seca prolongada na qualidade da água do reservatório gargalheiras na região tropical semiárida. In: SÍMPÓSIO DE RECURSOS HÍDRICOS DO NORDESTE, 12., 2014, Natal. Anais... Brasília: ABRH, 2014. Available from:< http://eventos.abrh.org.br/xiisrhn/ anais/>. Access on: 18 Oct. 2018.

GOMES, S. S.; FIGUEIREDO, A. V.; MEDEIROS, C. E. B. F. S.; BEZERRA, M. G. T. A.; BECKER, V.; MATTOS, A. Alteração do estado trófico de dois reservatórios da região semiárida brasileira durante um evento de seca prolongada. In: SIMPÓSIO BRASILEIRO DE RECURSOS HÍDRICOS, 21., 2015, Brasília. Anais... Brasília: ABRH, 2015. Available from: http://www. evolvedoc.com.br/sbrh/detalhes-1049_alteracao-do-estado-troficode-dois-reservatorios-da-regiao-semiarida-brasileira-durante-umevento-de-seca-prolongada>. Access on: 19 Oct. 2018.

HUSZAR, V. L. M.; SILVA, L. H. S.; MARINHO, M. M.; DOMINGOS, P.; SANT'ANNA, C. L. Cyanoprokariota assemblages in eight productive tropical Brazilian aters. Hydrobiologia, v. 424, n. 1, p. 67-77, 2000. http://dx.doi.org/10.1023/A:1003996710416. 
INMET - INSTITUTO NACIONAL DE METEOROLOGIA. Índice de Precipitação Padronizada (SPI). Brasília, 2014. Available from: <http://www.inmet.gov.br/portal/index.php?r=clima/ indicePrecipitacaoPadronizada>. Access on: 15 Dec. 2014.

IPCC - INTERGOVERNMENTAL PANEL ON CLIMATE CHANGE. Summary for policymakers. In: FIELD, C. B.; BARROS, V. R.; DOKKEN, D. J.; MACH, K. J.; MASTRANDREA, M. D.; BILIR, T. E.; CHATTERJEE, M.; EBI, K. L.; ESTRADA, Y. O.; GENOVA, R. C.; GIRMA, B.; KISSEL, E. S.; LEVY, A. N.; MACCRACKEN, S.; MASTRANDREA, P. R.; WHITE, L. L. (Eds.). Climate Change 2014: Impacts, Adaptation, and Vulnerability. Contribution of Working Group II to the Fifth Assessment Report of the Intergovernmental Panel on Climate Change. Cambridge: Cambridge University Press, 2014. p. 1-32.

JEPPESEN, E.; BRUCET, S.; NASELLI-FLORES, L.; PAPASTERGIADOU, E.; STEFANIDIS, K.; NÕGES, T.; NÕGES, P.; ATTAYDE, J. L.; ZOHARY, T.; COPPENS, J.; BUCAK, T.; MENEZES, R. F.; FREITAS, F. R. S.; KERNAN, M.; SØNDERGAARD, M.; BEKLIOĞLU, M. Ecological impacts of global warming and water abstraction on lakes and reservoirs due to changes in water level and related changes in salinity. Hydrobiologia, v. 750, n. 1, p. 201-227, 2015. http://dx.doi. org/10.1007/s10750-014-2169-x.

JESPERSEN, A. M.; CHRISTOFFERSEN, K. Measurements of chlorophyll-a from phytoplankton using ethanol as extraction solvent. Hydrobiologia, v. 109, p. 445-454, 1987.

MCCUNE, B.; MEFFORD, M. J. PC-ORD. Multivariate analysis of ecological data. Version 6.0. Oregon: MjM Software Design, 2011.

MCKEE, T. B.; DOESKEN, N. J.; KLEIST, J. The relationship of drought frequency and duration to time scales. In: Conference on Applied Climatology, 8., 1993, Anaheim. Proceedings... Boston: American Meteorological Society, 1993. p. 179-183.

MEDEIROS, L. C.; MATTOOS, A.; LÜRLING, M.; BECKER, V. Is the future blue-green or brown? The effects of extreme events on phytoplankton dynamics in a semi-arid man-made lake. Aquatic Ecology, v. 49, n. 3, p. 293-307, 2015. http://dx.doi.org/10.1007/ s10452-015-9524-5.

MENDONÇA JÚNIOR, J. R.; AMADO, A. M.; VIDAL, L. O.; MATTOS, A.; BECKER, V. Extreme droughts drive tropical semi-arid eutrophic reservoirs towards CO2 sub-saturation. Acta Liminogica Brasiliencia (Online), v. 30, n. e101, 2018. http://dx.doi. org/10.1590/S2179-975X1517.

MISHRA, A. K.; SINGH, V. P. A review of drought concepts. Journal of Hydrology (Amsterdam), v. 391, n. 1-2, p. 202-216, 2010. http://dx.doi.org/10.1016/j.jhydrol.2010.07.012.

MOOIJ, W. M.; DE SENERPONT DOMIS, L. N.; JANSE, J. H. Linking species- and ecosystem-level impacts of climate change in lakes with a complex and a minimal model. Ecological Modelling, v. 220, n. 21, p. 3011-3020, 2009. http://dx.doi.org/10.1016/j. ecolmodel.2009.02.003.
MOSS, B.; KOSTEN, S.; MEERHOFF, M.; BATTARBEE, R. W.; JEPPESEN, E.; MAZZEO, N.; HAVENS, K.; LACEROT, G.; LIU, Z.; DE MEESTER, L.; PAERL, H.; SCHEFFER, M. Allied attack: climate change and eutrophication. Inland Waters, v. 1, n. 2, p. 101-105, 2011. http://dx.doi.org/10.5268/IW-1.2.359.

MURPHY, J.; RILEY, J. P. A modified single-solution method for the determination of phosphate in natural waters. Analytica Chimica Acta, v. 27, p. 31-36, 1962. http://dx.doi.org/10.1016/ S0003-2670(00)88444-5.

NASELLI-FLORES, L.; BARONE, R. Steady-state assemblages in a Mediterranean hypertrophic reservoir. The role of Microcystis ecomorphological variability in maintaining an apparent equilibrium. Hydrobiologia, v. 502, n. 1-3, p. 133-143, 2003. http://dx.doi. org/10.1023/B:HYDR.0000004276.11436.40.

NASELLI-FLORES, L.; BARONE, R. Water-level fluctuations in Mediterranean reservoirs: setting a dewatering threshold as a management tool to improve water quality. Hydrobiologia, v. 548, n. 1, p. 85-99, 2005. http://dx.doi.org/10.1007/s10750-005-1149-6.

ROCHA JÚNIOR, C. A. N.; COSTA, M. R. A.; MENEZES, R. F.; ATTAYDE, J. L.; BECKER, V. Water volume reduction increases eutrophication risk in tropical semi-arid reservoirs. Acta Liminogica Brasiliencia (Online), v. 30, n. e106, 2018. http://dx.doi. org/10.1590/S2179-975X2117.

SEMARH - SECRETARIA DE ESTADO DO MEIO AMBIENTE E DOS RECURSOS HÍDRICOS DO RIO GRANDE DO NORTE. Dados de volume. Natal, 2014. Available from: < http// www.semarh.rn.gov.br//>. Access on: 10 Dec. 2014.

SOARES, M. C. S.; MARINHO, M. M.; AZEVEDO, S. M. F. O.; BRANCO, C. W. C.; HUSZAR, V. L. M. Eutrophication and retention time affecting spatial heterogeneity in a tropical reservoir. Limnologica, v. 42, n. 3, p. 197-203, 2012. http://dx.doi. org/10.1016/j.limno.2011.11.002.

VALDERRAMA, J. C. The simultaneous analisys of total nitrogen and phosphorus in natural waters. Marine Chemistry, v. 10, n. 2, p. 109-122, 1981. http://dx.doi.org/10.1016/0304-4203(81)90027-X.

VIEIRA, V. P. P. B. Sustentabilidade do semiárido brasileiro: desafios e perspectivas. Revista Brasileira de Recursos Hídricos, v. 7, n. 4, p. 105-112, 2002. http://dx.doi.org/10.21168/rbrh.v7n4.p105-112.

\section{Authors contributions}

Aline do Vale Figueiredo: Participated in the execution of the monitoring, sample analysis, data analysis, bibliographical revision, discussion, paper writing and translation.

Vanessa Becker: Contributed to the conception of the work, execution of monitoring, data acquisition and treatment, discussion and writing supervision. 